\title{
The Call and Tasks of a Prophet: An Exegetical Analysis of Jeremiah 1:4-10
}

\author{
Julius Ndishua' \\ 1 Nigerian Baptist Theological Seminary, Ogbomoso, Nigeria (NBTS)
}

\begin{abstract}
This article argues that the concept of a call to ministry may not be the same as the period of the Prophets. The issue of call to ministry remains a bone of contention among the Christian communities today. It is a bone of contention because people have different views on the issue of call. Some see the call to ministry from God's perspective, while others see it from the perspective of human beings. The fundamental question is: what does it mean to have a call and task to ministry. This paper has examined the call and tasks of a prophet in Jeremiah 1:4-10. The approach for this study was exegetical. The findings reveal that the call and tasks of a prophet in Jeremiah 1:4-10 disclose the sovereignty of God in deciding the fate of a person before the foundation of the world. Thus, the call and tasks of Jeremiah were a completed action in the mind of God before the actualization of it in the future. This article posits that Christian scholars should educate the church that no two calls are the same in the Bible. Scholars should also dissuade the church from using people without a clear call to pastoral ministry.
\end{abstract}

Correspondence Julius Ndishua Email: ndishuajulius@gmail.com Publication History Received 1st February, 2022 Accepted 17th February, 2022 Published online 28th February, 2022

\section{Keywords: Call, Task, Prophet, Ministry, Church}

\section{INTRODUCTION}

The concept of a call to ministry today may not be the same as compared to the era of the Prophets. It is one thing to experience the call to faith in Christ Jesus and another thing entirely to experience the call to serve either as a pastor, apostle or prophet. The need to serve either as a pastor or a prophet comes from God. However, the issue of call to ministry remains a bone of contention among the Christian communities today. It is a bone of contention because people have different views on the issue of call. Some see the call to ministry from God's perspective while others see it from the perspective of human beings.

It is not uncommon to note that there may be some who are into the gospel ministry today without a call. They perhaps are interested in the entitlements and the fame of being a pastor, an apostle or a prophet in this dispensation without a good grasp of what it takes to have a call and task of being in ministry. The prophets of old, especially Jeremiah, Isaiah and Moses experienced a call to ministry. The fundamental question is: what does it mean to have a call and task to ministry? This paper examines the call and functions of a prophet in Jeremiah 1:4-10 through an exegetical approach. 


\section{EXEGESIS OF JEREMIAH 1:4-10}

\section{Introduction to the Book of Jeremiah}

The book of Jeremiah in the English translations of the Bible falls within the section that some call the 'Major Prophets'; while, the Hebrew Bible situates it among the 'Latter Prophets'. ${ }^{1}$ On the other hand, R.K. Harrison posits that the book of Jeremiah precedes the book of Ezekiel. He further notes that according to one of the 'rabbinic traditions' Jeremiah should be placed ahead of the later prophets. The book of Jeremiah comes after the 'twelve Minor' Prophets in the Peshitta translation. ${ }^{2}$ On a similar note, James Adeyanju suggests that the book of Jeremiah is the largest of all of the prophetic books in the Hebrew Bible. The twelve so-called Minor Prophets put together cannot equate to the book of Jeremiah. ${ }^{3}$ Jeremiah is of a class of its own. This may suggest that there are words in the book of Jeremiah in the Hebrew Bible that are not found elsewhere.

The book of Jeremiah is unique among the prophetic books in the Hebrew Bible. One aspect of this uniqueness is because it consists of three different kinds of literary materials namely: 'poetic oracles', 'numerous prose sayings' and 'narratives'. ${ }^{4}$ Ernest W. Nicholson submits that the poetic oracles are largely from Jeremiah while the historical narrative on the biography of the Prophet is from Baruch. ${ }^{5}$ William Holladay cites Jeremiah 2-23; 30-31 and 46-51 as an area where poetic oracles appear while the biographical information is located in 26-29 and 32-44. ${ }^{6}$ Elmer Leslie notes that poetry, prose and prose speeches are familiar genres of the book of Jeremiah. ${ }^{7}$ Andrew Hill and John Walton agree that Jeremiah 26-29, and 32-45 are described as biographical narratives in the book. In these biographical narratives, the Prophet is described in the third person; which may suggest that it is inclusion either by Baruch or by some other disciples at a much later date. ${ }^{8}$

\section{Background to the Book of Jeremiah}

The Prophet Jeremiah prophesied during the reign of King Josiah. Josiah got to power at the age of eight, and by the age of twenty (628 B.C), he embarked on reforming the worship system of Judah. ${ }^{9}$ Jeremiah's confession (Jer. 1:2) suggests that he was of the same age bracket as King Josiah. ${ }^{10}$ Harrison situates events like the Josiah reforms in Judah and Jerusalem; the death of 'Ashurbanipal' the king of Assyrian, that gave room for the Babylonian to assume independence under the leadership of 'Nabopolassar' (626-605 B.C.), and Psammetichus regrouping in Egypt (664-610 B.C) with an adverse effect on the people in the southern kingdom as some concerns that surround the early beginning of the call of Jeremiah. God called him during this period to 'rebuke, warn, console, and exhort' his kinsmen. ${ }^{11}$ In line with Harrison, Olugbenga Olagunju concurs that Jeremiah describes the people of Judah as 'covenant-breakers'; hence his call was to warn them to repent or face God's judgment in the future. ${ }^{12}$ George Folarin asserts that "although Jeremiah knew that

Brevard S. Childs, Introduction to the Old Testament as Scripture (Philadelphia: Fortress Press, 1979), 309.

2 R. K. Harrison, Introduction to the Old Testament (Grand Rapids, Michigan: William B. Eerdmans Publishing Company, 1969), 801.

3 James O. Adeyanju, Introduction to Biblical Prophecy, Prophesying, and Prophets (Ilorin, Kwara State: Amazing-Grace Print-media, 2014), 103.

4 Ernest W. Nicholson, The Book of Jeremiah Chapter 26-52 (London: Cambridge University Press, 1975), 10.

5 Nicholson, The Book of Jeremiah Chapter 26-52.

6 William Holladay, Jeremiah: Spokesman out of Time (Philadelphia: Pilgrim Press Book, 1974), 11.

Elmer A. Leslie (translator), Jeremiah (New York, Abingdon Press, 1954), 18.

8 Andrew E. Hill and John H. Walton, A Survey of the Old Testament (Grand Rapids, Michigan: Zondervan Publishing House, 2000), 327.

$9 \quad$ Hill and Walton, $A$ Survey of the Old Testament, 426.

10 William Sanford LaSor, David Allan Hubbard and Frederic Wm. Bush, Old Testament Survey (Grand Rapids, Michigan: William B. Eerdmans Publishing Company, 1982), 404. Jack R Lundbom suggests that some scholars situate the age of Jeremiah somewhere between 18 and 25 . They argue that the prophetic ministry of a prophet begin the moment he is called. However, Lundbom opine that the age is either 12 or 13. He compares this with that of the 'boy' Samuel under Eli supervision and the call came to him a three different instances (1 Sam. 2:11 18, 21, 21, 26). Jack R. Lundbom, "Jeremiah (prophet)" in the Anchor Bible Dictionary Volume 3 H-J David Noel Freedman (ed) (New York: Doubleday, 1992), 686.

11 Harrison, Introduction to the Old Testament, 803.

12 Olugbenga Olagunju, A Concise Introduction to the Old Testament (Takie, Ogbomoso: Ogunniyi Publishers, 2014), 276. 
Judah was heading towards disaster in the form of judgment, he exhorted her to repent to avoid the catastrophe (3:1-4:4)." ${ }^{\prime 3}$ From this assertion, one can deduce that after God's warning, preceded His judgment. Jeremiah warned the people to repent from their wicked ways. In line with Folarin's idea, Emmanuel Itapson and George Janvier, opine that "a long succession of corrupt, idolatrous and politically minded religious leaders had taken the people past the point of no return (spiritually). Babylon would be the tool of God's judgment." 14 Itapson and Janvier are right to say the leaders of Judah led the people away from God with their corrupt practices. It is common to say that a nation rises and falls depending on the kind of leadership in place. Roy Honeycutt describes Jeremiah as a prophet of 'renewal and hope'. He spent his time and energy persuading the people of Judah to return to their God..$^{15}$

\section{Authorship}

The authorship of the book of Jeremiah is a bone of contention because of the "intermixture of prose and poetry within the book." 16 The assumption that "prophetic materials' are generally poetic is not workable in the context of Jeremiah. Poetry and prose are predominant in Jeremiah. This aspect gives room for scholars to conclude that the prose and poetry sections are works of more than one person. The prose section of the book may be an addition that one of Jeremiah's disciples added or it could be the work of the editors. The introductory section, as well as the narratives, are written in prose. The content of both the poetry and prose, according to Robert Cate, suggests that Jeremiah is the primary source of the material. ${ }^{17}$

\section{Dating of the Book of Jeremiah}

There are always several arguments that surround the dating of events, especially dating of biblical books. Like other biblical books, the dating of Jeremiah is subject to debate. The following scholars: Norman Gottwald and Cate situate Jeremiah's prophecy from 626 B.C to 586 B.C ${ }^{18}$; while Victor Matthews and James Moyer say it is from 640 to 609 B.C. ${ }^{19}$ On the other hand, Charles Copper considers the end of the Assyrian domination in (953-612 B.C.) and the early beginning of the 'Neo-Babylonian age' in (612-540 B.C) as the approximate range of dating Jeremiah's prophecy. ${ }^{20}$ This paper deduces from the above analysis that the date is 626 B.C to 586 B.C. because it relates the Prophet to the reign of Josiah and the destruction of the temple by the Babylonians.

\section{The Immediate Context of Jeremiah 1:4-10}

Jeremiah 1:4-10 is situated within the broader context of Jeremiah 1:1-19 that focuses on the "call and commission' of Jeremiah. ${ }^{21}$ The literary genre of Jeremiah 1:4-10 is a 'call narrative'. ${ }^{22}$ This call narrative could equally be termed narrative prophecy.

\section{Textual Analysis of Jeremiah 1:4-10}

Douglas Stuart notes that the task of the textual variant is compelling and essential to achieving any meaningful interpretation. ${ }^{23}$ In the same line, Ellis Brotzman posits that the study of textual variants makes use of manuscripts like 'Septuagint, the Samaritan Pentateuch, the Vulgate and the Masoretic text' just to

13 George Folarin, Studies in Old Testament Prophecy (Plateau State, Nigeria: ACTS, 2004), 93.

14 Emmanuel Itapson and George Janvier, A Study of the Major and Minor Prophets of the Old Testament: A Textbook for Africa (Jos: Africa Christian Textbooks, 2005), 34.

15 Roy L. Honeycutt, Jeremiah: Witness Under Pressure (Nashville, Tennessee: Convention Press, 1981$), 6$.

16 Robert L. Cate, An Introduction to the Old Testament and its Study (Nashville, Tennessee: Broadman Press, 1987$), 358$.

17 Cate, An Introduction to the Old Testament and its Study, 359.

18 Norman K. Gottwald, The Hebrew Bible: A Social-Literary Introduction (Philadelphia: Fortress, 1985), 395 ; Cate, 362.

19 Victor Mathews and James Moyer, The Old Testament Text and Content (Peabody Massachusetts: Hendrickson Publishers, Inc., 1997), 165.

20 Charles M. Cooper, Jeremiah (Philadelphia: Lutheran Church Press, 1971), 8.

21 Gleason L. Archer, Jr., A Survey of Old Testament Introduction Revised Edition (Chicago: Moody Press, 1974$), 359$.

22 Matthews and Moyer, The Old Testament Text and Content 165.

23 Douglas Stuart, Old Testament Exegesis: A Primer for Students and Pastors $4^{\text {th }}$ edition (Louisville, Kentucky: Westminster John Knox Press, 2009), 83. 
name a few. The Masoretic Text is the most reliable because of the presence of textual error. ${ }^{24}$ The writer used the 1967-1977 editions of Biblia Hebraica Stuttgartensia in this paper; For instance, editors of the Masoretic Text suggest that the word 'to me' is rendered in the Septuagint as $\pi \rho$ ' The Masoretic Text rendition is preferred in this study due to the variance.

Masoretic text Jeremiah 1:4-7²5

4

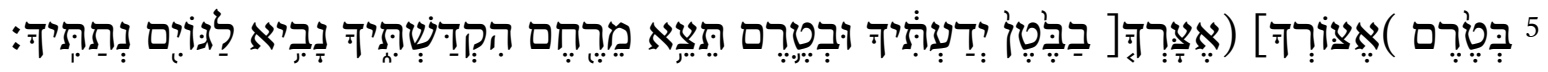

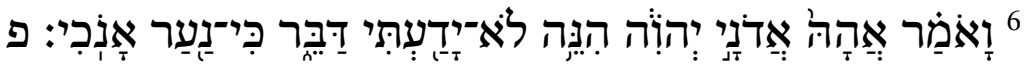

7

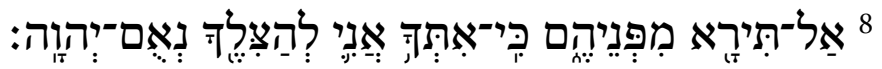

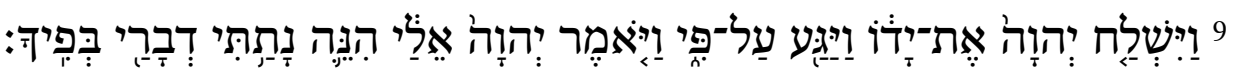

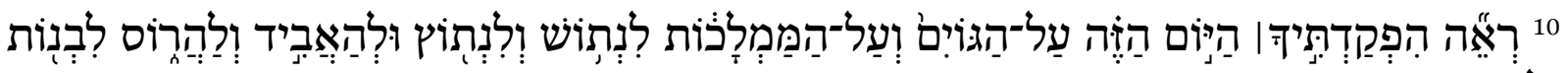

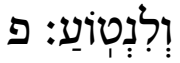

\section{Rough Translation of Jeremiah 1:4-10}

1:4 Then it came, the word of the LORD, to me, to saying

1:5 in before that, I formed you, in the womb, I knew you, and in before, you were born, out of the womb, I consecrated you, Prophet, to the nations, I appointed you,

1:6 then I said, alas, Lord, the LORD, behold, I do not know, how to speak, I am, because a youth

1:7 Then he said, the LORD, to me, do not say, a youth, I am, because, everywhere, I send you, you shall go, and, all that, I command you, you shall speak.

1:8 Do not be afraid, of their faces, for with you, I am, to deliver you, declares the LORD

1:9 Then he stretched out, the LORD, His hand, then he touched, my mouth, then he said, the LORD, to me, behold, I have put, my words, in your mouth

1:10 See, I have appointed you, the day, this, over the nations, and over the kingdoms, to pull up, and to pull down, and to destroy, and to throw down, to build, and to plant

\section{Smooth Translation of Jeremiah 1:4-10}

1:4 Then the word of the LORD came to me, saying,

${ }^{24}$ Ellis R. Brotzman, Old Testament Textual Criticism: A Practical Introduction (Grand Rapids, Michigan: Baker Books, 1994), 127.

25 Bibleworks-[c:/program files/bibleworks7/init/bw700.swc] accesed November 15 ${ }^{\text {th }}, 2021$. 
1:5 Before I formed you in the womb I knew you, and before you were born, I consecrated; I appointed you a prophet to the nations.

1:6 Then I said, “Alas, the sovereign LORD! I do not know how to speak because I am a youth.

1:7 Then the LORD said to me; "Do not say, 'I am a youth,' Because everywhere I send you; you shall go; And all that I command you, you shall speak.

1:8 "Do not be afraid of their faces, for I am with you to deliver you," declares the LORD

1:9 Then the LORD stretched out His hand and then he touched my mouth, Then the LORD said to me, "Behold, I have put my words in your mouth".

1:10 "See, I have appointed you this day over the nations and over the kingdoms, to pull up and to pull down, and to destroy, and to throw down, to build and to plant."

\section{Structural analysis of Jeremiah 1:10-17}

The structural analysis of Jeremiah is divided into four units. These four units are God's call to Jeremiah (Jer. 1:4-5); Jeremiah's Response to God's Call (Jer. 1:6); God's response to Jeremiah's fears (Jer. 1:7-8) and God's commission to Jeremiah (Jer. 1:9-10).

\section{Syntactical analysis of Jeremiah 1:4-10 God's call to Prophet Jeremiah (Jer. 1:4-5)}

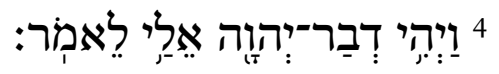

Translation: 1:4 Then the word of the LORD came to me, saying,

The word 'then' shows a continuation of the previous discourse in Jeremiah 1:1-3 to the dialogue in Jeremiah 1:1-4. In Jeremiah 1:1-3, the human lineage of the Prophet, the geographical location, the reign of several kings that indicates the time and date the Prophet sequentially received the word of the LORD is linked to

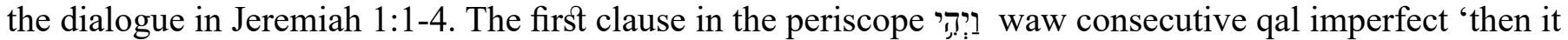

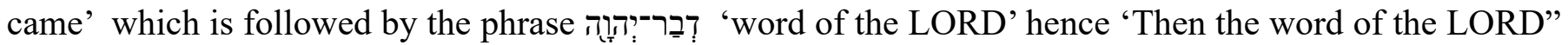
establishes a completed action. Jeremiah's relationship with the LORD is a long-lasting one. He does not refer to a different word in Jeremiah 1:4; rather, it is the same word as previously received. God reveals himself to Jeremiah through his word. It is certain that through this divine initiation; the Prophet is confident of his relationship with God. He is confident in his reporting that what he received was the word of the LORD. True prophets hear from God and communicate what He has instructed them. The word of God is the word of the Prophet. ${ }^{26}$ The Prophet assures his audience that 'the word of the LORD' was revealed to him. The declaration of the word according to Campbell Morgan reveals that it is the "supreme value of the book." ${ }^{27}$ This implies that what the Prophet was called to preach is the word that he received from the LORD. The word לִאמָר 'saying' is a prepositional infinitive construct serving as a direct speechmaker; ${ }^{28}$ which also connotes that it was a systematic discourse. From this verse, the Prophet is specific about the mode of dialogue. The LORD perhaps spoke to him through a "vision". ${ }^{29}$ God speaks, and he is still speaking today.

26 J. L. Berquist, "Prophetic Legitimation in Jeremiah", Vetus Testamentum, Vol 39. 2 (1989), 129-139.

27 Campbell Morgan, studies in the Prophecy of Jeremiah (Los Angeles: Fleming H. Revell Company, 1955$), 11$.

28 James D. Price, An Exegetical and Expository Syntax of Biblical Hebrew (np, 2016), 180.

29 Jack R. Lundbom, Jeremiah 1-20 A New Translation with Introduction and Commentary Vol21 A (New York: The Anchor Bible, 1999), 227. 


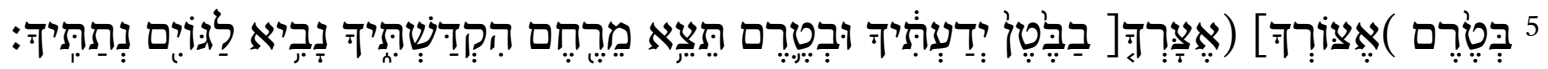

Translation: 1:5 "Before I formed you in the womb, I knew you, and before you were born, I consecrated; I appointed you a prophet to the nations."

The word טֶר is an adverb that indicates time. The action in God's mind was already completed. Jeremiah was not there; instead, he is reporting what he heard. It frightens when you are told 'before I formed you in the womb I knew you' Jeremiah existed in the mind of God long before his real formation in the

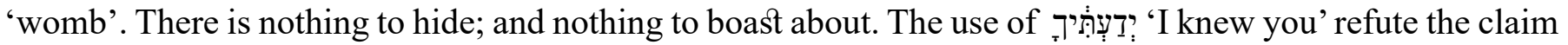
that God does not know the future as open theists believe. ${ }^{30}$ God reveals to Jeremiah that every facet of his life and being is not new to Him. All that Jeremiah will do, even the things on his mind are known; what is the point trying to hide your real self before the one who knew you before you were formed in the womb. The mating of his parents and the night or the day of his conception was known. God could choose to do otherwise, but He is faithful, and He honours his words.

To recall, it is stated above that the word טֶרֵ 'born' God knows everything from the beginning of time to end of all matters. Jeremiah was set apart before

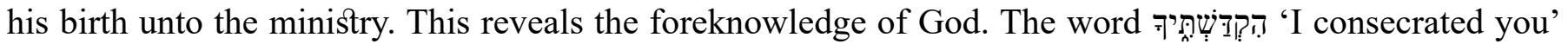
connotes that Jeremiah was consecrated before his birth for God's assignment. This equally could mean

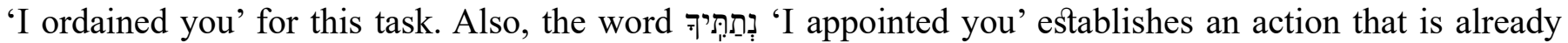

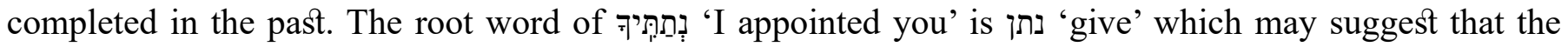
Prophet is a gift of God unto the nations. Jeremiah's call is not from a human being nor from a council of elders rather he is called by God to be a נִָבְיא 'prophet'. True prophets do not assume their calls, they acknowledge that unless God calls them, they are not his Prophet. Jeremiah is called to be a prophet 'to the nations'. The word לפ 'to the nations' suggests that the Prophet Jeremiah shall speak 'the word of the $L O R D$ ' as a called prophet beyond the borders of Judah to other nations. He will confront kings with the word of God. This may equally mean that the Prophet is called to be 'international' in his worldview as he proclaimed 'the word of the LORD'. The word of the LORD is equally meant to be preached to others outside of Judah. Carolyn Sharp attests that Jeremiah's call to be a prophet to all nations reveals the supremacy of God over the universe. ${ }^{31}$ Jeremiah's response to God's call is explained in the next section.

\section{Jeremiah's Response to God's Call (Jer. 1:6)}

\section{6}

Translation: 1:6 Then I said, "Alas, the sovereign LORD! I do not know how to speak because I am a youth. The word 'Then' shows the flow of thought from the previous section that reveals God's intention to Jeremiah in a dialogue. The word אָָּה in in an interjection or exclamation that expresses humanity in Jeremiah. The

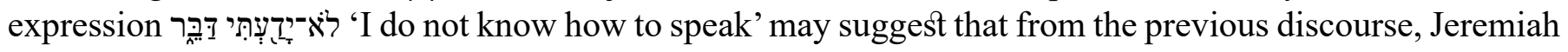
did not understand the LORD. He is told that everything about him is known and there is nothing to hide. The inability to speak should not be a problem because the LORD who formed him is in control of the situation. But then, it was customary for him to express his fears as a mere human. The word 'a youth' connotes that Jeremiah could not imagine himself standing before the kings, people of Judah and other nations to bring about the understanding of God's word. This expression of his real humanity before the sovereign God is not uncommon; Moses did same. He made attempts to escape the call of God to be a prophet unto the nations because of trivial issues.

30 John M. Frame, No Other God: A Response to Open Theism (Phillipsburg, New Jersey: P \$ R Publishing, 2001$), 23$.

31 Carolyn J. Sharp, Prophecy and Ideology in Jeremiah. David J. Reimer (ed) (London: T \& T Clark, 2003 ), 422. 


\section{God's Response to Jeremiah's Fears (Jer 1:7-8)}

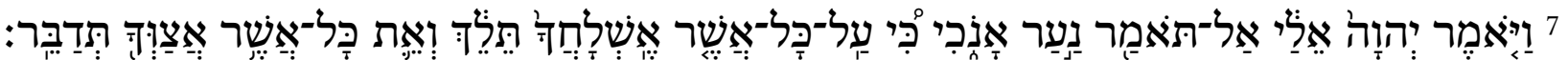

Translation: 1:7 Then the LORD said to me; "Do not say, 'I am a youth,' Because everywhere I send you; you shall go; And all that I command you, you shall speak.

The discourse continues with the introduction of 'then' a waw consecutive that links the previous speech in Jeremiah 1:6 to God's response in Jeremiah 1:7. The tone of this clause not say, I am a youth' suggests two things: 1. God is unhappy with Jeremiah's self-assessment; for it reveals disbelief for what God can do. 2. He is not seeking Jeremiah's consent; instead, Jeremiah is obliged to follow

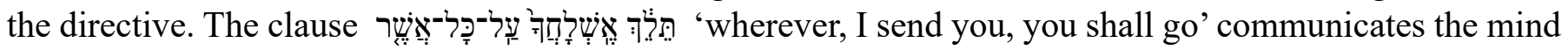
of God is a hard term and tone to the Prophet Jeremiah. He will not only go, but he is supposed to say only what God commands. The word 'I command you' is a piel verb which denotes the intensity that the Prophet has no word of his own. He is to entirely rely on God as well as receive from Him before he can go on to proclaim. The word רִּ is another piel verb that stresses the intensity of God's command to the Prophet. Thus, Jeremiah is to speak nothing else than the word of God. He is not to proclaim his imagination nor tell a story; rather, his duty is to proclaim the word of the LORD. The word is supposed to be the major thing in his ministry. The command is non-negotiable; rather, obedience is paramount at all times.

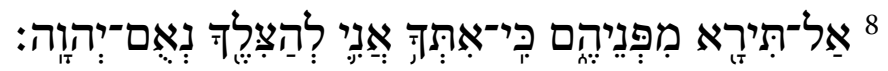

Translation: 1:8 "Do not be afraid of their faces, for I am with you to deliver you," declares the LORD

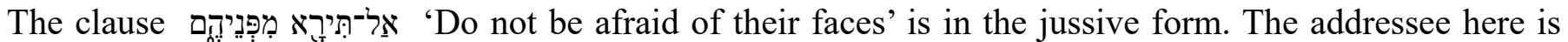
an individual, precisely Jeremiah. The use of the negative אֵל אל 'not' instead of 'not' describes the jussive nature of the clause. ${ }^{32}$ Brotzman asserts that in Hebrew, volition is expressed in three different ways, namely: 'jussive', 'cohortative' and 'imperative'. The imperative mood according to Brotzman is an expression of 'direct positive commands' while jussive and cohortative are an expression that conveys rather more indirect volition that is the will of someone ('desire', 'wish', 'request', 'advice', 'invitation', 'exhortation', 'order', or 'command'). ${ }^{33}$ God orders Jeremiah not to be afraid of the people, the rulers and the kings as well as the other nations. He is not to be frightened of them because His presence will always be with the Prophet Jeremiah to deliver him from the hands of the people and things that may attempt to militate against His plan. God's assurance, protection and deliverance are a guarantee to His Prophet Jeremiah. Jeremiah is commissioned and empowered to take the message to the nation.

\section{God's Commission to Jeremiah (Jer. 1:9-10)}

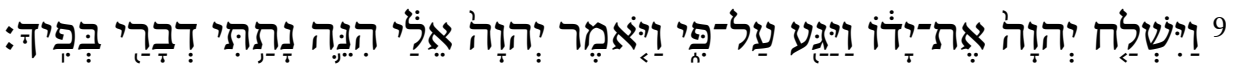

Translation: 1:9 Then the LORD stretched out His hand and then he touched my mouth, Then the LORD said to me, "Behold, I have put my words in your mouth".

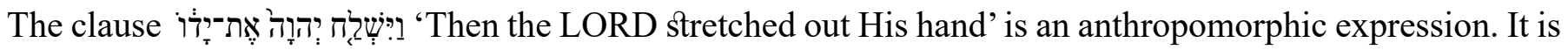

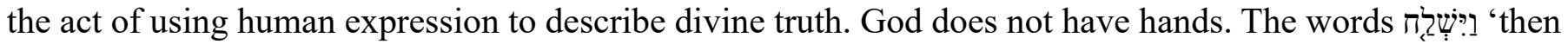

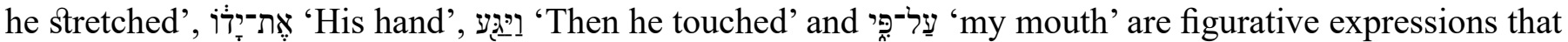
appear in a progressive manner. The clause אתָ-יָּז 'His Hand' is possibly a metaphorical description of God's

32 John H. Dodson, Learning Biblical Hebrew $2^{\text {nd }}$ ed. (Grand Rapids, Michigan: Baker Academic, 2005), 123.

33 Brotzman, Old Testament Textual Criticism: A Practical Introduction 174-175. 
authority, power, strength, and protection. The clause reveals that God is always present to either bless His people, punish evildoers or protect His people. In this context, God stretches His hands to bless Jeremiah, the Prophet. The word yיㅣ 'then he touched' is an expression of blessing. He bestowed on Jeremiah the blessing of His word. The word becomes like food to the Prophet. It is this word that the Prophet will spend his entire life preaching. Thus, the clause 'Behold I have put my word in your mouth' is a completed action. The word has the power to change wicked and evil people.

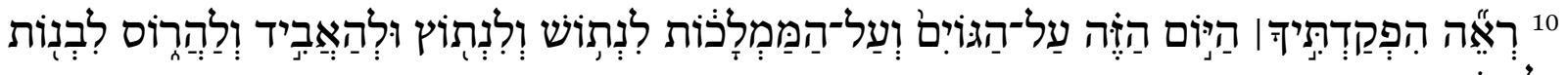

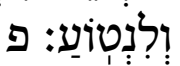

1:10 "See, I have appointed you this day over the nations and over the kingdoms, to pull up and to pull down, and to destroy, and to throw down, to build and to plant."

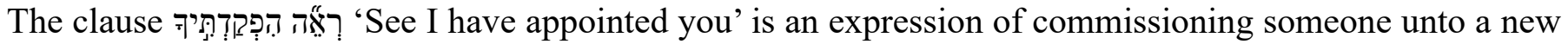

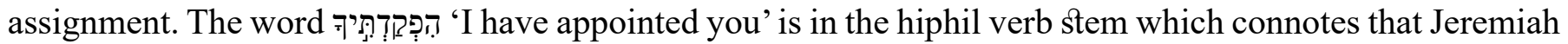
is the causative agent through whom God will reach the people of Judah and the other nations with the message of judgment and restoration. Harlow asserts that "Jeremiah thought he was just a boy or servant, but God set him higher than the kings of nations. Josiah was the king of the little country Judah, but there were three great Gentile empires: Assyria, Babylon and Egypt." ${ }^{34}$ Jeremiah will use the authority of God to announce the rise and fall of the nations, as stated above. The task of the Prophet is described using two symbols or imageries, namely: a farmer and a builder. Famers are required to weed their farm so that the crop can grow better as well as builders would have to break down an old structure to construct a new one. Thus the Prophet would preach judgment and restoration to the people of Judah and other nations. Huey asserts that Jeremiah 1:10 "anticipates the two-fold ministry of Jeremiah. He will announce messages of judgment and encouragement and hope." ${ }^{35}$ The message of judgment and hope remind 'covenant breakers' to repent and worship the LORD as it was expected of them.

\section{Inferences from Jeremiah 1:4-10}

The previous section focused on the exegesis of Jeremiah 1:4-10. This section deals with the inferences of Jeremiah 1:4-10. The 'nature of the call' and 'the tasks of a prophet' ${ }^{36}$ are the main focus of this section, as explained below.

\section{The Nature of the Call}

A prophet is one who has a relationship with the LORD. Jeremiah 1:4 reveals an existing relationship between the LORD and the Prophet. Also, a prophet is one who can recognize the voice of the LORD when He speaks. This is an indication that the Prophet of God knows the voice of his maker. Thompson suggests that "the way in which a call from God came to a potential prophet is impossible to define since God makes his approach in very personal ways." 37 From this assertion, one can confidently state that no two calls are the same. The one who is called understands how best the LORD's extended His call to him or her. The 'call' may be audible or through a vision. Thus, the LORD determines the call of a prophet as well as he speaks to a prophet in a way he or she will understand Him.

34 R. E. Harlow, Jeremiah Prophet of God (Canada: Everyday Publications Inc., 1989), 11.

35 F. B. Huey, Jr. The New American Commentary: An Exegetical Theological Exposition of Holy Scripture NIV Text Jeremiah and Lamentation (Nashville, Tennessee: Broadman Press, 1993), 52.

36 These insights are from Rev. Dr. O.B. Oladejo's debriefing after Seminar Presentation November 10 2020.

37 J. A. Thompson, The New International Commentary on the Old Testament: The Book of Jeremiah (Grand Rapids, Michigan: William B. Eerdmans Publishing Company, 1980), 147. 
There is a uniqueness to every call recorded in the Scriptures. ${ }^{38}$ In Jeremiah 1:5, there are three aspects 'before you were formed, I knew you, I consecrated, and I appointed you' describes the nature of the call of a prophet. 'Before you were formed, I knew you' reveals God's sovereignty and foreknowledge over the life of His creatures, especially the call of a prophet. This knowledge of God equally tells that; He knows the future of His creatures from the very beginning of their lives. Besides, a prophet perhaps existed in the mind of God before he exists at all. Huey opines that the word 'formed' is the same word used in Genesis 2:7, which has a relationship with the word 'Potter' as used in Jeremiah 18:2-3. He notes that the LORD created Jeremiah to be a spokesman unto the nations. The word 'knew' denotes a relationship between God and His Prophet. ${ }^{39}$ The consecration of this Prophet is unique from all others in the scriptures, as stated above. The LORD set him apart before his birth, with the intention that he will become a causative agent through whom He will reach out to His people and the nations as explained above. Derek Kidner is perhaps right in his opinion that the 'consecration and appointed' means "God's act of taking or consecrating his servant, for he takes in order to give, in many senses of that word." ${ }^{40}$ Kidner in line with Jeremiah 1:4-5 suggests that the LORD

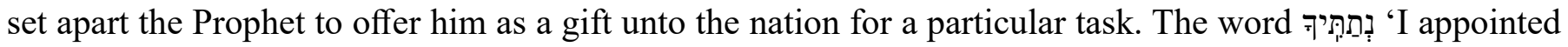
you' is from the root 'gift'. The Prophet is perhaps described as God's consecrated gift unto the nations. A prophet does not only recognize the Sovereignty of the LORD; he is equally one who recognizes his frailty. Also, he is one who does not want to be a prophet (Jer. 1:6). Harrison suggests that the call of God perhaps triggers an 'emotional conflict' within the Prophet to the extent that it provoked him to disclose his timidity and inexperience to no avail before the LORD. ${ }^{41}$ Thus, Jeremiah 1:6 reveals that there are times that human resistance to the call of God may not prevail as expected by the individual. It is undeniable that God's plan and purpose are sovereign and may always prevail irrespective of the circumstances.

The call of Yahweh to a prophet is often a command to be obeyed. This call may ignite fear in the heart of the individual at the first instance, especially someone who does not want to be a prophet. Thus, a prophet is one who can be afraid of the unknown or express fearfulness (Jer. 1:6-7). In this text (Jer. 1:6-7), the Prophet is obliged to obey God's command, as well as declare it. The presence of God is always with a prophet. The call of a prophet engendered divine touch. Thus, the LORD is always close to his Prophet more than he expects. Every called prophet has at least a task to perform for the LORD.

\section{The Tasks of a Prophet}

The primary task of a prophet is perhaps to 'declare', 'speak', or 'proclaim' the Word of God. These descriptions denote that a prophet is a 'speaker', a 'mouthpiece' or a 'spokesman' for the LORD. ${ }^{42}$ VanGemeren suggests that prophets are 'speakers'. They are members of the council of God as well as 'spokesmen' for the LORD in the society where they find themselves. The prophetic declaration and criticism of a prophet often ruin the hope of their audiences. ${ }^{43}$ The text Jeremiah 1:9-10 reveals some six things that a prophet is called to do namely: 'to pull up, to pull down, to destroy, to throw down, to build, and to plant'.

Walter Brueggemann submits that the first four verbs namely: 'pull up', 'pull-down', 'destroy' and 'throw down' are negative; which may suggest that no matter how fortified a city may claim to be or claim to have a standing defence force, their effort will not be able to secure a community against the LORD especially when it is under the judgment of God. The verbs 'build; and 'plant' may imply that only God has the power to create newness out of nothing. He will bring a new beginning in the life of His people. ${ }^{44}$ Sharp submits that those nations that refuse to obey the precept of the LORD are sure to be carried away from their territory to captivity; however, restoration awaits those that have made obedience a duty. The scope of the

38 Willem A. VanGemeren, Interpreting the Prophetic Word: An Introduction to the prophetic literature of the Old Testament (Grand Rapids, Michigan: Zondervan, 1990), 43.

39 Huey, The New American Commentary, 50.

40 Derek Kidner, The Message of Jeremiah (Downers Grove, Illinois: Inter-Varsity Press, 1987), 25.

41 R. K. Harrison, An Introduction and Commentary Jeremiah and Lamentations (Downers Grove, Illinois: Inter-Varsity Press, 1973), 49.

42 Hobart E. Freeman, An Introduction to the Old Prophets (Chicago: Moody Press, 1968), 39-40.

43 VanGemeren, Interpreting the Prophetic Word, 43.

44 Walter Brueggemann, A Commentary on Jeremiah: Exile and Homecoming (Grand Rapids, Michigan: William B. Eerdmans Publishing Company, 1998), 25. 
prophetic ministry is beyond the borders of Judah; it extends to other nations. ${ }^{45}$

The call and task of a prophet using Jeremiah as a prototype indicate that the call to serve as a gospel proclaimer emanates from God. The individuals God calls at times may have little or no say to resist the His call. The call and tasks of Jeremiah teach that those that sense the call of God often than not may make attempts to resist or reject for a personal reason. The job description of the Prophet in this text is unique to him. He is called to prophesy to people who have broken their covenant with their God as well as preach to other nations. Thus, it takes courage to accept God's call because attached to almost every call is a price to pay. On the other hand, the LORD knows the life of his servant from the very beginning. Olusayo Oladejo submits that "the LORD knows the beginning from the beginning" ${ }^{46}$ Here, the point suggests that the LORD is eternal and He is self-sufficient.

Another task of a prophet is to cause the people to see God in his prophetic ministry. The message he proclaims will not come from his imagination; instead, it is supposed to be the very Word of God. Thus, the Prophet is supposed to spend time with God before reaching out to the people of God within his immediate surrounding and beyond. This is a call of absolute dependence upon God. Furthermore, many feel dejected to comply with the call of God for fear of the unknown. Some may reject because they are shy and may not be bold to confront repressive and cruel leadership as well as society. However, God's choice of individuals for service is always His sovereign choice. Thus, the tasks may seem to be difficult, but the one who calls promises that He will preserve, protect and deliver His servants.

\section{CONCLUSION}

This study employed the syntactical analysis of Jeremiah 1:4-10. From this exegetical study, the writer has underscored that the call and tasks of a prophet in Jeremiah 1:4-10 reveal the sovereignty and foreknowledge of God in deciding the fate of his creature before the foundation of the world. In this context, the call and tasks of Jeremiah were a completed action in the mind of God before the actualization of it in the future. The call of Jeremiah was irrevocable and irresistible. Jeremiah was consecrated and ordained to be a prophet before his birth. Thus, the Prophet Jeremiah had no option other than to obey the instructions of God and speak only when he is allowed to do. The word of the Prophet for people becomes the very word of God.

\section{BIBLIOGRAPHY}

Adeyanju, James O. Introduction to Biblical Prophecy, Prophesying, and Prophets. Ilorin, Kwara State: Amazing-Grace Print-media, 2014.

Archer, Jr. Gleason L. A Survey of Old Testament Introduction Revised Edition. Chicago: Moody Press, 1974. Berquist, J. L. "Prophetic Legitimation in Jeremiah", Vetus Testamentum, Vol 39. 2 (1989), 129-139.

Brotzman, Ellis R. Old Testament Textual Criticism: A Practical Introduction. Grand Rapids, Michigan: Baker Books, 1994.

Brueggemann, Walter. A Commentary on Jeremiah: Exile and Homecoming. Grand Rapids, Michigan: William B. Eerdmans Publishing Company, 1998.

Cate, Robert L. An Introduction to the Old Testament and its Study. Nashville, Tennessee: Broadman Press, 1987.

Childs, Brevard S. Introduction to the Old Testament as Scripture. Philadelphia: Fortress Press, 1979. Cooper, Charles M. Jeremiah. Philadelphia: Lutheran Church Press, 1971.

Dodson, John H. Learning Biblical Hebrew $2^{\text {nd }}$ edition. Grand Rapids, Michigan: Baker Academic, 2005. Folarin, George. Studies in Old Testament Prophecy. Plateau State, Nigeria: ACTS, 2004.

Frame, John M. No Other God: A Response to Open Theism. Phillipsburg, New Jersey: PR Publishing, 2001. Freeman, Hobart E. An Introduction to the Old Prophets. Chicago: Moody Press, 1968. Gottwald, Norman K. The Hebrew Bible: A Social-Literary Introduction. Philadelphia: Fortress, 1985. Harlow, R. E. Jeremiah Prophet of God. Canada: Everyday Publications Inc., 1989.

45 Sharp, Prophecy and Ideology in Jeremiah, 425.

46 Olusayo B. Oladejo, "Seminar on Exegetical Studies in the Prophetic Books", (NBTS, Ogbomoso, 2020), np. 
Harrison, R. K. Introduction to the Old Testament. Grand Rapids, Michigan: William B. Eerdmans Publishing Company, 1969.

Holladay, William. Jeremiah: Spokesman out of Time. Philadelphia: Pilgrim Press Book, 1974.

Honeycutt, Roy L. Jeremiah: Witness Under Pressure. Nashville, Tennessee: Convention Press, 1981.

Hill, Andrew E. and John H. Walton, A Survey of the Old Testament. Grand Rapids, Michigan: Zondervan, 2000.

Huey, Jr F. B. The New American Commentary: An Exegetical Theological Exposition of Holy Scripture NIV Text Jeremiah and Lamentation. Nashville, Tennessee: Broadman Press, 1993.

Kidner, Derek. The Message of Jeremiah. Downers Grove, Illinois: Inter-Varsity Press, 1987.

Itapson, Emmanuel and George Janvier. A Study of the Major and Minor Prophets of the Old Testament: A Textbook for Africa. Jos, Nigeria: Africa Christian Textbooks, 2005.

LaSor, William Sanford David Allan Hubbard and Frederic Wm. Bush, Old Testament Survey. Grand Rapids, Michigan: William B. Eerdmans Publishing Company, 1998.

Leslie Elmer A. (translator), Jeremiah. New York, Abingdon Press, 1954.

Lundbom, Jack R. Jeremiah 1-20 A New Translation with Introduction and Commentary Vol21 A. New York: The Anchor Bible, 1999.

Mathews, Victor and James Moyer, The Old Testament Text and Content. Peabody

Massachusetts: Hendrickson Publishers, Inc., 1997.

Morgan, Campbell. Studies in the Prophecy of Jeremiah. Los Angeles: Fleming H. Revell Company, 1955. Nicholson, Ernest W. The Book of Jeremiah, Chapter 26-52. London: Cambridge University Press, 1975.

Olagunju, Olugbenga. A Concise Introduction to the Old Testament. Takie, Ogbomoso: Ogunniyi Publishers, 2014.

Oladejo, Olusayo B. "Seminar on Exegetical Studies in the Prophetic Books", NBTS, Ogbomoso, 2020.

Price, James D. An Exegetical and Expository Syntax of Biblical Hebrew. Np, 2016.

Stuart, Douglas. Old Testament Exegesis: A Primer for Students and Pastors $4^{\text {th }}$ edition. Louisville, Kentucky:

Westminster John Knox Press, 2009.

Sharp, Carolyn J. Prophecy and Ideology in Jeremiah. David J. Reimer (ed). London: T \& T Clark, 2003.

Thompson, J. A. The New International Commentary on the Old Testament: The Book of Jeremiah. Grand

Rapids, Michigan: William B. Eerdmans Publishing Company, 1980.

VanGemeren, Willem A. Interpreting the Prophetic Word: An Introduction to the prophetic literature of the Old Testament. Grand Rapids, Michigan: Zondervan, 1990.

\section{ABOUT AUTHOR}

Rev Julius Ndishua is an ordained Minister at the Cameroon Baptist Convention. He holds a Master's degree in Old Testament language and literature from the Nigerian Baptist Theological Seminary-Ogbomoso, Nigeria (NBTS). He is currently a PhD candidate in Old Testament language and literature in the same institution. He has research interests in style and code-switching in the Old Testament. 